\title{
Reconstruction of thoracic esophagus with pediculated diaphragmatic flap in $\operatorname{dogs}{ }^{1}$
}

\author{
Reconstrução do esôfago torácico \\ com retalho pediculado do diafragma em cães
}

\section{Neusa Margarida Paulo², Wagner Miranda ${ }^{3}$, Ingrid Bueno Atayde ${ }^{4}$, Juarez Távora de Siqueira Junior ${ }^{5}$, Elisa Maria Rennó Azevedo ${ }^{6}$, Flávia Gontijo de Lima ${ }^{6}$, Leandro Guimarães Franco ${ }^{6}$, Cynthia Mara Custódio Faria ${ }^{6}$}

1. Research performed at Department of Veterinary Medicine, Veterinary Medicine College, Federal University of Goiás (UFG), Brazil.

2. Full Professor, Veterinary Medicine College, UFG, Brazil.

3. General Surgeon. Santa Casa de Misericórdia de Goiânia, Brazil.

4. Fellow PhD degree, Veterinary Medicine College, UFG, Brazil.

5. Full Professor, Department of Morphology, Medicine College, UFG, Brazil.

6. Graduate Student, Veterinary Medicine College, UFG, Brazil.

\begin{abstract}
Purpose: To verify whether pediculated diaphragmatic flaps were suitable to correct iatrogenic wounds in dog's esophagus injuries. Methods: Seven dogs were submitted to resection of a segment of the esophagical wall, which was then corrected by suturing a pediculated diaphragm flap. Endoscopic evaluation of the esophagical wall was done forty days after the surgical procedure. Results: Three animals died, one due to implant ischemia, caused by strangulation of the phrenic artery; other due to wound infection; and the last, due to mediastinitis. Scar retraction was observed, however, there was no stenosis, allowing the passage of a $9,8 \mathrm{~mm}$ probe with no difficulty. The limits between the implants and the native esophagus were indistinguishable, and the implant was covered by esophageal mucosa. Conclusion: The diaphragmatic flaps are suitable on the restoring of continuity in dog's thoracic esophagus.
\end{abstract}

Key words: Esophagus. Diaphragm. Esophagoplasty. Animal Experimentation. Dogs.

\section{RESUMO}

Objetivo: Verificar se retalhos diafragmáticos pediculados seriam adequados para correção de defeitos iatrogênicos do esôfago do cão. Métodos: Sete cães foram submetidos à ressecção de um segmento da parede esofágica, o qual foi corrigido por meio da sutura de um pedículo diafragmático pediculado. Um animal morreu devido à isquemia do implante causada pelo estrangulamento da artéria frênica, outro devido à infecção da ferida cutânea e outro devido a mediastinite. Aos 40 dias após o procedimento fez-se um exame endoscópico dos animais nos cães sobreviventes. Resultados: Observouse retração cicatricial sem repercutir em estenose, permitindo a passagem de sonda de $9,8 \mathrm{~mm}$, sem dificuldade. Os limites entre os implantes e o esôfago nativo se apresentaram indistinguíveis e o implante estava recoberto por mucosa esofágica. Conclusão: Os retalhos diafragmáticos são adequados na restauração da continuidade do esôfago torácico do cão. Descritores: Esôfago. Diafragma. Esofagoplastia. Experimentação Animal. Cães.

\section{Introduction}

In spite of the always-evolving surgical advances, esophagic perforations in men, as well as in other species, represent a great problem for surgeons to overcome, being considered an important thoracic emergency ${ }^{1}$. Esophagic injuries are frequent in small animals clinic routine, and veterinarian surgeons frequently lack satisfactory techniques for their correction. Ruptures of the esophagus are related to outer or inner traumas such as those caused by firing guns and sharp instruments among others. Foreign bodies and complications in esophagoscopy may also cause rupture of the esophagus, where the first may lead to small perforations, which can be augmented by endoscopic procedures ${ }^{2}$. Esophagical stenosis in dogs usually occurs in the distal portion of thoracic esophagus and, even in such cases, a treatment option is the resection and anastomosis of the esophagus ${ }^{3}$. In men, mortality rates due to esophagical perforations can be reduced if the treatment is established in up to 12 hours after the beginning of its evolution ${ }^{4}$. Delay in the diagnosis and treatment of this condition may lead to the development of necrotic mediastinitis and impossibility to proceed with primary esophageal repair ${ }^{5}$. The success of the latter, which must be considered a priority, is based not only in the time elapsed on the diagnosis, but also in the careful intra-operative, which involves the debridment of the devitalized tissues, the identification of the esophagical layers, the abundant irrigation and the complete mediastinal and pleural draining. The success of such procedures will also depend on the site of the wound, the nature and the condition of esophagic tissue, and on the general conditions of the patient ${ }^{1}$. Fails, 
presented as leakiness, due to primary esophagoplasty are due mainly to the particular anatomic constitution of the esophagus. This organ has neither a serosa covering, nor the presence of omentum ${ }^{6,7}$. Another fact that can be blamed for such complication is the presence of contamination or widespread infections, which lead to a great chance of occurring dehiscence or fistulae, and these may determine the need of a new intervention. The ideal protocol would be a resection of esophagical injury followed by anatomosis of the remaining segments with no tension. However, in cases of extensive damages in the esophagical wall, approaching the borders after the dissection may not be possible ${ }^{8}$. Such situations require the use of substitutes in order to reestablish the continuity of the organ. Several materials have been used on substitutive esophagoplasty procedures, amongst which are: the rhomboid muscle ${ }^{7}$, autogenous pericardium ${ }^{9}$ and jejune segment ${ }^{10}$. Diaphragmatic pedicles have been used in substitutive esophagoplasty in men since $1948^{11}$. The diaphragm is a strong, elastic, and well vascularizated muscle, also resistant to necrosis and bearer of a good regeneration capability. Its vascularization derives from the lower phrenic arteries; pericardium phrenic arteries, inter mammary and intercostal arteries. Its enervation has a peripheral distribution originated from phrenic nerves' branches, allowing the section of the muscle without the denervation of the remaining diaphragm. It is possible to remove wide bands of the diaphragm and still close the defect without tension ${ }^{12}$. The simplicity of the technique as well as its physiologic basis, the prevention of fistulae and diverticles in the site of the esophageal defect are encouraging factors ${ }^{6,13}$. Diaphragmatic flaps may be used on esophagorrhaphy for the treatment of bronchopleural fistula and reinforcement suture in pneumoectomy ${ }^{11,4,14}$. Such results are credited to the blood supply of the pedicle, which is, hence, considered practical, safe and particularly indicated on the repair of the defects or fistulas and to protect the line suture in the thoracic cavity ${ }^{11}$.

\section{Methods}

The project of this research was submitted to, and approved by, the Committee of Research Ethics at Federal University of Goiás. Seven mongrel and clinically healthy dogs were used. After an adaptation period, the dogs were submitted to a pre-operative endoscopic examination. For the surgical procedure, there was water and food fastening of six and twelve hours, respectively. The pre-anesthetic procedure was carried with Chlorpromazine ( $1 \mathrm{mg} / \mathrm{kg} / \mathrm{IV})$, and Atropine sulfate $(0,004 \mathrm{mg} / \mathrm{kg} / \mathrm{IM})$. The induction of anesthesia was done with Thiopental sodium $(15 \mathrm{mg} / \mathrm{kg})$ and maintained with Halothane in closed circuit. As the animals achieved anesthesia they were intubated with oralgastric probe. Thoracic esophagus was approached through the ninth right intercostal space. After identification, the esophagus was isolated and a defect was created in its right lateral wall. A band of diaphragm, compatible with the esophagical defect, was sectioned to form a pedicle, which was cranially deflected, provided that there was no tension nor rotation over it (Figure 1). The diaphragmatic flap was sutured to the borders of the esophageal wall, on simple and interrupted stitches in a single plan using 4-0 monocryl thread (Figure 2). For phrenorraphy chromate categut 2-0 was used in simple continuous stitches. The diaphragmatic defect in the basis of the pedicle was not sutured. The thoracic cavity was cleansed with $\mathrm{NaCl} \mathrm{O}, 9 \%$ solution, and examined in order to find any bleeding point. The thoracic wall was sutured with simple interrupted stitches using surgical chromic gut 2. Skin was stitched with 2-0 cotton threads. The postoperative therapy was carried with $2,5 \%$ Enrofloxacin ( $5 \mathrm{mg} / \mathrm{kg} / \mathrm{IM} /$ for eight days), Tenoxican (IV/ for 3 days), and local dressing with Iodine Povidine. The animals were submitted to alimentary restraint during seven days, receiving intravenous fluid therapy (glucose solution $5 \%$, with vitamin complex added. After this period, they were given liquid diet, orally, for five days. The diet consisted of dog food, grained in a kitchen shaker. For the next five days, they were fed a paste-like dog food. Then, normal diet was restored. Evaluations consisted in routine clinical examinations, which included assessment of body temperature, frequency and respiratory amplitude. Endoscopic evaluation of the esophagical wall was done forty days after the surgical procedure.

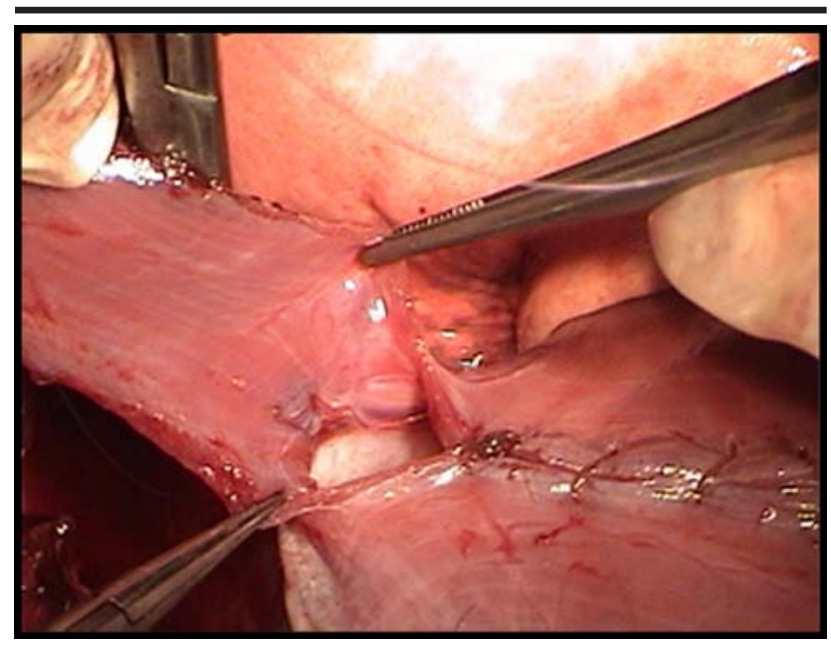

FIGURE 1 - Diaphragmatic flap reflected cranially. It is noticed the maintenance of the defect in its base.

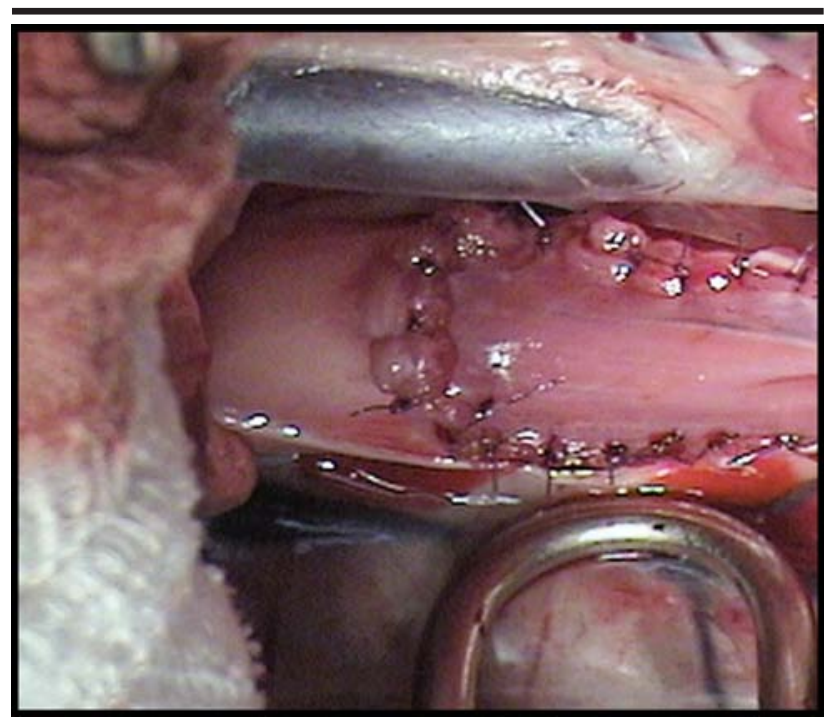

FIGURE 2 - Diaphragmatic flap sutured to the borders of the esophageal defect. 


\section{Results}

In the postoperative period, there was one death in the $30^{\text {th }}$ day, which was imputed to respiratory infection and purulent dermatitis. Two animals suffered euthanasia, one in the $3^{\text {rd }}$ day due to ischemic necrosis of the pedicle, and the other in the $13^{\text {th }}$ due to the infection of the surgical wound. The remaining animals exhibited normal respiratory pattern, and intrathoracic liquids or any other signal compatible with fistulas were not detected. After restoring normal diet feeding, only one dog presented post-prandial regurgitation, thus returning to liquid diet. This animal was treated during 30 days with Ranitidine Chlorhydrate, $300 \mathrm{mg}$, s.i.d., not presenting regurgitation afterwards. The dog euthanaised in the $13^{\text {th }}$ day of the postoperative had flexible adherences of the right diaphragmatic lung lobe to the sites of implantation, and of the liver to the diaphragmatic defect in the pedicle's base. The light of the esophagus presented normal caliber, and, externally, there was continuity between native wall and the diaphragmatic segment implanted (Figure 3). The dog that died in the $30^{\text {th }}$ day showed a macroscopic image similar to the first, and, in the luminal surface of the esophagus, sutures fixing the implant to the borders of the esophagical wall were seen. The esophagoduodenoscopies done at 40 days revealed in all the animals the following findings: clean organ, standard caliber and peristalsis, presence of subtle scar retraction, presence of fibrotic tissue, and friable, red mucosa, showing recent mucous covering and central red tissue similar, in aspect, to muscle tissue (Figure 4). The scar retraction did not lead to stenosis, allowing the passage of $9,8 \mathrm{~mm}$ probe with no difficulty. The stomach of the dog that presented regurgitation showed moderate edema and enanthema/exanthema, and plane erosions on the surface of whole the organ, its esophagus looked similar to the others. After the end of the experiment, the animals were conducted for donation to the Veterinary Hospital of Federal University of Goias.

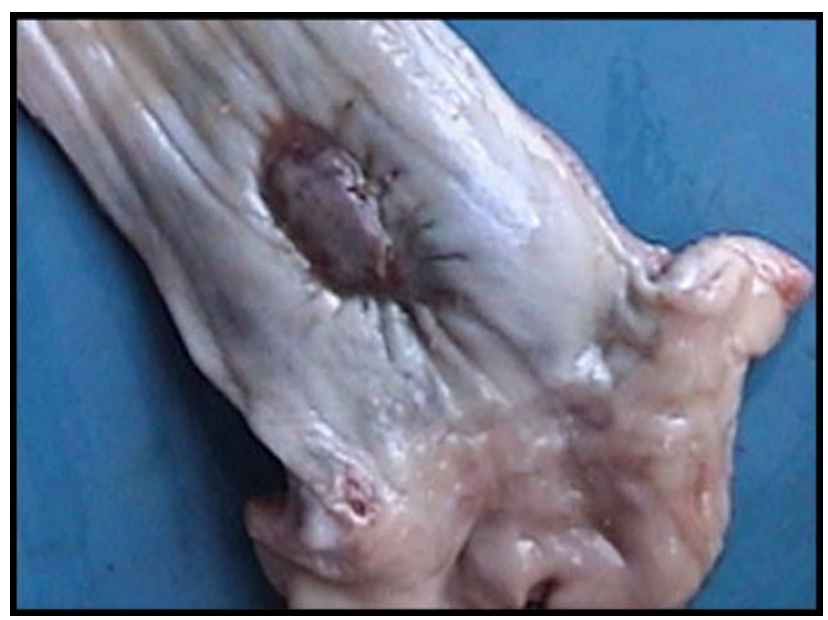

FIGURE 3 - Luminal face of dog' esophagus submitted to esophagoplasty with diaphragmatic flap

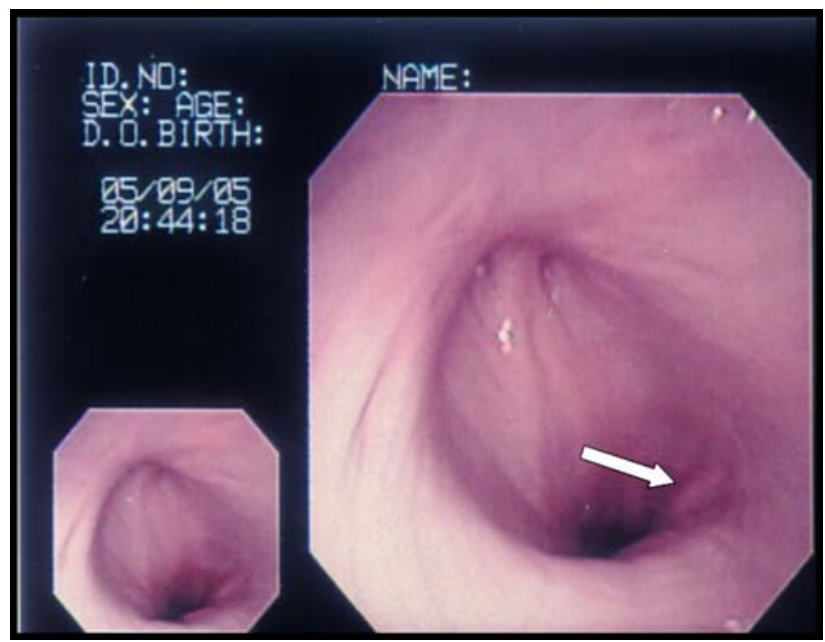

FIGURE 4 - Endoscopic image of dog's esophagus submitted to esophagoplasty with diaphragmatic flap. Notice the scar retraction (arrow)

\section{Discussion}

The approach of the thoracic cavity through the $9^{\text {th }}$ intercostal space is adequate for the exposition of the esophagus and diaphragm. This segment of the esophagus proved that the diaphragmatic pedicle could be mobilized conveniently for the correction of wounds in structures in the third medium or caudal (posterior in men) portion of the thoracic cavity. In addition, these sites of the esophagus are, in dogs, frequently involved in the perforation lesions or in the stenosis ${ }^{3}$. This approach provided protection of the vagus nerve as well as the selection of a phrenic artery, upon which the pedicle is based. The preservation of these vases must be considered as priority to the execution of the technique, for it provides enough blood supply in the implanted site ${ }^{13}$. It was also observed, in the necropsy of a dog that vessel strangulation evolves into necrosis of the implant and further to mediastinitis. In addition, deficient vascularization of the pedicle may lead to the contraction and development of scar on the graft ${ }^{12}$, which is a frequent complication of esophagical surgery procedure. The base of de pedicle was purposely left open to prevent its strangling, however to men it has been recommended the implant of a mersilene mesh, to prevent diaphragm hernia ${ }^{14}$. Knowing that the preparation of diaphragmatic pedicle involves the opening of the peritoneal cavity, permanent occlusion of the hernia ring was also considered to avoid intercavitary dissemination of microorganism in case of infection ${ }^{11}$. Such procedure might not be necessary in dog, since it was seen in the necropsia of the euthanized dog the defect was completely occluded. The reconstruction of thoracic structures using diaphragmatic pedicle flap seems to be facilitated by quick angiogenesis in the site of the implant. Also, endoscopic findings in human patients submitted to this technique present quick and uncomplicated healing between 3 and 4 weeks after the implantation procedure ${ }^{15}$. Endoscopic image shown in 
dogs at the $24^{\text {th }}$ day corroborates such observations, for at this time the esophagus was completely healed, also showing epithelization the implanted area. The subtle retraction observed did not bother swallowing function of these animals; they were fed and recovered their previous weight. Regurgitation presented in one dog may possibly be due to gastroduodenitis or to the hiatal hernia, seen in the endoscopic examination, for there was remission of the symptoms after treatment.

\section{Conclusion}

The diaphragmatic flaps sutured to the borders of esophagic defects evolves into adequate restoring of continuity, presenting cicatrization and endoscopical image with very few alterations.

\section{References}

1. Bufkin BL, Miller Jr. JI, Mansour KA Esophageal perforation: emphasis on management. Ann Thorac Surg. 1996; 165:1447-52.

2. Stainki DR, Alves GES, Sallis ESV, Cadorin RL, Garcia FS, Beltran JER, Razia LE, Silva NR. Emprego de enxerto biológico na reconstrução de ferida experimental no esôfago cervical de ovinos. Arq Bras Med Vet Zootec. 2001; 53:1-8.

3. Adamama-Moraitou KK, Rallis TS, Prassinos NN, Galatos AD. Benign esophageal structure in the dog and cat: a retrospective study of 20 cases. Can J Vet Res. 2002;66(1):55-9.

4. Santis PB, Bourcheid T, Cunha A, Gonçalves L, Bolcato M, Romano G, Portela MT, Kisielevicks V, Loureiro ALRS, Silva LN, Simões JC. Retalho diafragmático em sutura esofagiana: trabalho experimental em cães. Rev Med Paraná. 1997;54:11-8.

5. Avissar E, Sheinfeld A, Lernau O. Repair of esophageal perforation with a diaphragmatic flap. Haref. 1992;123:22-4.
6. Critselis AN. Pedicle flap of the diaphragm for repair of esophageal injuries. Br J Surg. 1968;68:749-50.

7. Lucas AE, Snow N, Tobin GR, Flint Jr LM. Use of the rhomboid major muscle flap for esophageal repair. Ann Thorac Surg. 1982;33:619-23.

8. Delikaris KPH, Hatzipantelis KP, Filintatzi C, Kotakidou RE, Kitis G, Raptopoulus D. The use of a dura mater patch to cover oesophageal defects of different sizes: an experimental study in chickens. Eur J Surg. 1999;165:151-7.

9. Lugo ASB, Gonzales NH, Hernandez AA, Herrera AM, Alonso AG, Hermoso FG. La plastia pediculada de pericardio em la obturación de defectos esofágicos: estúdio experimental. Rev Esp Enf Ap Digest. 1982;62:165-70.

10. Smith DF, Ott DJ, Mcguirt WF, Albertson DA, Chen MYM, Gelfand DW. Free jejunal grafts of the pharynx: surgical methods, complications, and radiographic evaluation. Dysph. 1999;14:176-82.

11. Mineo TC, Ambrogi V. Early closure of the postpneumonectomy bronchopleural fistula by pedicled diaphragmatic flaps. Ann Thorac Surg. 1995;60:714-5.

12. Westaby S, Shepherd MP, Nohl-Oser HC. The use of diaphragmatic pedicle grafts for reconstructive procedures in the esophagus and tracheobronchial tree. Ann Thorac Surg. 1981;33:486-90.

13. Yong-Xian Y. Treatment of esophageal achalasia (cardiospasm) with diaphragmatic graft: report of 44 patients. Ann Thorac Surg. 1982;35:249-52.

14. Lardinois D, Horsch A, Krueger T, Dusmet M, Ris H-B. Mediastinal reinforcement after therapy and pneumonectomy: comparison of intercostal muscle versus diaphragm flaps. Eur J Cardiovasc Thorac Surg. 2002;21:74-8.

15. Mineo TC, Ambrogi V. The diaphragmatic flap: a multiuse material in thoracic surgery. J Thorac Cardiovasc Surg. 1999;118:1084-9.

\section{Correspondence:}

Neusa Margarida Paulo

Escola de Veterinária da Universidade Federal de Goiás

74001-910 - Goiânia - GO - Brazil

Phone:(55 62)3521-1596

Fax:(55 62)3521-1588

e-mail: nmp@vet.ufg.br
Conflict of interest: none Financial source: none

Received: August 08, 2006 Review: September 16, 2006 Accepted: October 20, 2006

\section{How to cite this article:}

Paulo NM, Siqueira Jr JT, Atayde IB, Miranda W, Azevedo EMR, Lima FG, Franco LG, Faria CMC. Reconstruction of thoracic esophagus with pediculated diaphragmatic flap in dogs. Acta Cir Bras. [serial on the Internet] 2007 Jan-Feb;22(1). Available from URL: http://www.scielo.br/acb. 